\title{
THE SALIENCE OF SAINTLINESS IN ISLAM: A SUFI PERSPECTIVE
}

\author{
Wael Hegazy \\ University of California Santa Barbara, United States \\ E-mail: wael_hegazy@ucsb.edu
}

\begin{abstract}
While materialism largely failed in achieving humanity's essential goal of attaining happiness in life, as it intensified people's attachment to the material world, spirituality represents an alternative way towards accomplishing ultimate joy. Multiple approaches have brought the value of spirituality. Classical saintly experience and practice have played a significant role in Islamic spirituality and became in its various forms integrated into social, political, and intellectual life. This paper discusses the ascetic practices of Sufis in approaching the ultimate spiritual goal of inner purification. While classical Sufism's disciplinary methods have varied significantly across time and place, in many cases, these practices revolve around obedience and asceticism. It then discusses the unique attributes Sufi saints are characterized that speak to the existence of more profound dimensions of reality such as Wilāya and Baraka and their impact on social life.
\end{abstract}

Keywords: Classical Sufism, Sainthood, Saintliness, Wilaya, Baraka, Islamic mysticism, Islamic asceticism.

Article history: Received: 02 December 2020 | Revised: 11 February 2021 | Accapted: 02 May 2021 | Available online: 01 June 2021

\section{How to cite this article:}

Hegazy, Wael. "The Salience of Saintliness in Islam: A Sufi Perspective". Teosofi: Jurnal Tasawuf dan Pemikiran Islam 11, no. 1 (2021): 1-19. https://doi.org/10.15642/teosofi.2021.11.1.1-19 


\section{Introduction}

The salience of religion in life has long preoccupied rhetoricians' minds, philosophers, academics, and others. In appreciation of devoutness and valuation of religious figures whose lives are dedicated only to God and salvation in the hereafter, William James $^{1}$ (1842-1910), the influential American philosopher and father of American psychology, argues that the "saintly character is the character for which spiritual emotions are the habitual center of the personal energy; and there is a certain composite photograph of universal saintliness, the same in all religions, of which the features can easily be traced." 2 Pope Francis underscores this spirituality in a recent sermon delivered on December 24, 2018, when he condemned the predominance of materialism and spiritual emptiness and encouraged the people to lead a less materialistic life. ${ }^{3}$ Under the pressures of a modern life that is primarily driven by a consumerist, capitalist spirit, almost at the expense of spirituality, saintly spirit remerges as a countermove or an alternative way of life, through which people can accept grief and suffering and, even, find elements of comforting solace in them.

While materialism largely failed in achieving humanity's essential goal of attaining happiness in life, as it intensified people's attachment to the material world and aspiration for material wealth, spirituality-on the other hand-represents an alternative way towards accomplishing ultimate joy and happiness. Materialism, as described by Carl Gustav Jung (d. 1961), involves "Achievement, usefulness, and so forth are the ideals which appear to guide us out of the confusion of crowding problems ... they may help us in striking over roots in the world, but they cannot guide us in the development of that wider consciousness to which we give the name of culture". 4 In other words, a materialistic tendency could satisfy worldly ideals, but it is mostly lacking in unworldly ideals or in bringing spiritual satisfaction.

\footnotetext{
1 James theory states the greatest "fruits of the religious life", and therefore the greatest justification for religion, is in saintliness.

${ }^{2}$ William James, The Varieties of Religious Experience (London: Routledge, 2002), 212.

${ }^{3}$ Quoted in Philip Pullella, "Remember the Poor and Shun Materialism, Pope Says on Christmas Eve", Reuters, 24 December, 2018.

${ }^{4}$ Carl Gustav Jung, Modern Man in Search of Soul, trans. W.S Dell and Cary F. Bynes (London: Routledge, 2005), 105.
} 
Therefore, this paper examines the significance of Sufism as a form of Islamic spirituality that aims to cultivate a saintly life characterized by a set of qualities such as altruism (itharr). These qualities are developed through a specific regimen of practices like asceticism (zubd) and remembrance (dhikr). I argue that Sufism can impact social life through the cultivation of virtues that constitute saintly life. It also contends that classical Sufi saints, such as Ibn 'Arabī' (d. 1240) and Abū Hāmid al-Ghazālīí (d. 1111), continue to provide potentials in contemporary society to achieve a saintly life stands in contrast to the materialistic attitudes of the world today. Consequently, Sufism still features prominently in many Muslims' lives since, according to Sufi saints themselves and Sufi practitioners, it possesses the possibility of living a more fulfilling life. It does this through its general conceptual components that allow for the experience and articulation of a deeper (or higher) level of reality and practical methods of self-discipline. While the disciplinary practices deployed by Sufis have varied significantly across time and place, in many cases, these practices revolve around obedience and asceticism.

First, I will discuss how Sufism provides alternatives to contemporary materialistic attitudes by discussing the concepts that speak to more profound dimensions of reality, such as wilaya, kashf, basira, and baraka. I will then discuss how this worldview is achieved, in part, through sets of practices such as hadra, mortification, and fasting aimed at cultivating obedience and poverty, both of which help to diminish a sense of self (ego). I argue that by subduing the individual ego and presenting individuals with a set of meanings beyond themselves and this material world, I think Sufism provides a salient solution to society's problems today. After discussing the concepts and practices, I will discuss the qualities of this saintly life in more detail.

5 Ibn 'Arabī was an Arab and Andalusian Muslim scholar, mystic, poet, and philosopher. His philosophical teachings underscore dominant worldviews in many parts of the Islamic world until the present time.

${ }^{6}$ Abū Hāamid al-Ghazālī is leading Muslim philosophers, jurists, theologians and mystic of Sunni Islam. His works in theology, Islamic jurisprudence (fiqh), and philosophy are still dominant in the modern Muslim mind. 


\section{Concept of Sufism and Significance}

Before proceeding in explanation of practices, attributes, and fruits of the saintly life, I prefer to shed light on the nature of Sufism as explained by Abū al-Qāsim al-Qushayrī (d. 1073), an Arab Muslim scholar and theologian, that the word $S \bar{u} f i$ is derived from safa $\vec{a}$ (purity). Thus, it means "assuming every sublime moral character trait and giving up every lowly one." While etymological definitions of Sufism differ, I want to emphasize through al-Qushayri's description is that Sufism entails the refinement of moral character, the acquisition of ethical traits, and the surrender of egoistic ('lowly') features. ${ }^{8}$

In addition to this ethical component, Sufism as an embodiment of spirituality in Islam is also a mystical tradition characterized by an ineffable nature. This is the most prominent feature of mystic sects analyzed by William James in Varieties of Religious Experience. ' Such mysterious nature is clearly explained through Jalāl al-Dīn al-Rūmì's (one of the many Sufi awliya à) stories. ${ }^{10}$ This depiction of those who try to approach the Sufi nature as: "The blind men, when they were made to touch an elephant, each described it according to the part of the body his hands had touched: to one the elephant appeared like a throne, to another like a fan, or like a water pipe, or like a pillar. But none was able to imagine what the whole animal would look like."11 Classical Sufi saints acknowledge such mystery and excuse others who do not fully understand their mystic nature because access to this mystical truth is achieved only through direct experience. It was narrated that Ibn 'Arabī, who was one of the greatest Andalusian awily $\vec{a}$, mentioned that ordinary people could not conceive the saints' speech because words have esoteric

\footnotetext{
7 Abu al-Qasim al-Qushayri, al-Qushayri's Epistle on Sufism, trans. Alexander Knysh (UK: Garnet Publishing Limited, 2007), 289.

${ }^{8}$ Etymological definitions have included attempts to define Sufi in relation to the Arabic for wool $(s \bar{u})$, meaning that it referred to what was worn by early ascetics (Nile Green, Sufism: A Global History (Oxford: Blackwell, 2012). A second definition attempts to link the Greek term for wisdom (sophia) to süfi, though arguments in this regard are unconvincing (Ibid). A third definition claims that the term is derived from 'people of the bench' (abl al-suffa), meaning those who would regularly sit in the Prophet's mosque in Medina (Ibid).

${ }^{9}$ Ibid., 242.

${ }^{10}$ Singular wati means "Close Fellow of God".

11 Annemarie Schimmel, Mystical Dimension of Islam (University of North Carolina Press: USA, 1975), 3.
} 
meanings. ${ }^{12}$ However, this mystical discourse, which Ibn 'Arabī helped develop through his works like Bezels of Wisdom, included a wealth of terminology that enriched classical Sufi thought by providing a means to express deep meanings resulting from Sufi practice and experience. In this regard, Schimmel contends that the study of Sufi exclusive symbols, pictures, and words opened the way for contribution to developments in Islamic literature, language, and arts. ${ }^{13}$ Therefore, one of the Sufi saints' roles has been to develop a language that enables individuals to communicate, ultimately ineffable experiences. In addition to this role, Sufi saints have also contributed by establishing paths or sets of well-defined practices that help individuals reach those experiences. ${ }^{14}$

\section{Mystical Practices}

Sufi saints adopt two primary forms of mysticism to show God's devotion by abstention from superficial appearance; the Mysticism of Infinity and Mysticism of Personality. ${ }^{15}$ The first emerged concerning Ibn 'Arabî's work. ${ }^{16}$ It required that the Sufi individual neglects his/her human desires and feels no difference between oneself and the Creator and even considers oneself the Creator. ${ }^{17}$ The second form, Mysticism of Personality, states that man and God's natural relationship as "creature and Creator" is often adopted by "the earlier Sufis," as Schimmel notes. ${ }^{18}$

While these mystical discourses played a role in elite circles, Sufi experience and practice also influenced society more broadly. Over time, it became in its various forms integrated into social, political, and intellectual life. In this regard, Nile Green, professor and a historian of Islamic India and Pakistan at UCLA, maintains that by 1100 the Sufi productivity stretches from the east to the west. By

\footnotetext{
12 Muḥammad Amīn b. Ābidīn, Radd al-Muhtār 'alā al-Durr al-Mukhtār: Sharḥ Tanwīr al-Absāir, ed. Ādil Aḥmad 'Abd al-Mawjūd et al., Vol. 6 (Riyadh: Dār 'Ālam alKutub, 2003), 379.

${ }^{13}$ Schimmel, Mystical Dimension of Islam, 7.

14 See al-Qushayri, al-Qushayri's Epistle, 17-74.

15 Schimmel, Mystical Dimension of Islam, 4.

${ }^{16}$ Ibid., 4.

17 Rabia Nasir and Arsheed Ahmad Malik, "Role and Importance of Sufism in Modern World," International Journal of Advancements in Research \& Technology 2, no. 1 (January 2013), 2.

${ }^{18}$ Schimmel, Mystical Dimension of Islam, 4.
} 
1500, their substantial presence and influential role and institutional footholds across the world, which was the extraordinary ascent, acted as social and intellectual linchpins of very different communities. ${ }^{19}$ One of its primary functions in this regard has been to provide a counterbalance to materialistic tendencies by attending to individuals' spiritual needs. This function may be shared by some other ideologies, beliefs, or groups, but it witnesses much more focus in Sufi thought. According to Sufi metaphysics, life is a journey; the first section of this journey of all beings from the source is called the "arc of descent," and the second part back to the source, the "arc of ascent." During this vast cosmic wayfaring, people find themselves here and now on earth as human beings. ${ }^{20}$

In reference to the significance of mysticism in Islam, Macdonald $^{21}$ indicates that in his work, The Religious Attitude and Life in Islam, from the earliest ages of Islam, mysticism is adopted on a broader dimension than Christianity to the extent that it became a mystical faith. ${ }^{22}$ Although Islamic mysticism is manifested in Sufi ideology, Sufism's spiritual role in the past is as substantial as in the modern time. Besides, Sufism opens for people a gate to discover the world beyond their imagination. ${ }^{23}$ Sufism also "wakens individuals to the inner world and apprehension of divine realities so that their consciousness may be transformed." ${ }^{24}$ In these various roles of facilitating a direct encounter with the divine and experiencing a world beyond the corporeal, visible worlds that as a form of mysticism, Sufism provides potentials for developing the saintly life. However, these mystical experiences, which help to situate individuals in relation to a world beyond the material world, are reinforced by sets of practices that can generally be described as asceticism.

\footnotetext{
${ }^{19}$ Green, Sufism, 71.

20 Seyyed Hossein Nasr, The Garden of Truth: The Vision and Promise of Sufism, Islam's Mystical Tradition (New York: Harper Collins, 2008), 6.

${ }^{21}$ Duncan Black MacDonald (1863-1943) was an American Orientalist. He studied Semitic languages at Glasgow and then Berlin, before teaching at the Hartford Theological Seminary in the United States starting in 1893, and he founded the first school in the U.S. devoted to Christian missionary work among the Muslims of the Middle East.

22 Duncan Black Macdonald, The Religious Attitude and Life in Islam (Chicago: University of Chicago Press, 1909), 159.

${ }^{23}$ Nasir and Malik, Role and Importance of Sufism, 2.

${ }^{24}$ John Baldock, The Essence of Sufism (n.p.: Arcutrus Publishing, 2005).
} 
Asceticism (zubd) is the substantial practice to which classical saints consciously resort as a sign of obedience and loyalty to God. Asceticism, as practiced in Sufism, involves a set of practices aimed at disciplining the self in order to eliminate the desires of the ego (nafs) and cultivate sincerity of intention, thereby making acts of devotion oriented toward God alone, as al-Ghazālī notes. ${ }^{25}$ William James contends that through asceticism and sacrifices, saints happily express their loyalty to the higher power. ${ }^{26}$ It is the unique training for saints to be qualified for saintly life. In the beginning, it seems hard for Sufi practitioners, but a while later, they involve in such practices and even enjoy them to the extent that they cannot imagine their lives without asceticism. The self-pressure and bodily-tension are argued as healthy matters by James. ${ }^{27}$ It is considered a sort of self-training for enduring sufferings and overriding the hardships in life to enter the pure divine life, as al-Qushayrī explains. ${ }^{28}$ Schimmel refers to what makes the suffering and pains are acceptable for Sufis by arguing that love of God makes the saint strong enough to endure pains and even enjoy them, along with his conviction that these pains are just tests from God $^{29}$ Sufism only gives its fruits to individuals if they diligently practice "Mujähada (spiritual struggle), experience, endurance, and patience." 30 One of the primary practices that propel individuals along the path is dhikr, which in its most general sense involves the repetition of phrases accompanied by concentrated thought. This may be done on its own or in preparation for another practice commonly known as the hadra. In the hadra, groups gather together to perform the dhikr collectively, often accompanied by bodily movements and, in some extreme cases, may include forms of self-torture. These sessions are about circular head and body movements of men while standing all night and containing body torture. However, they enjoyed such suffering of their bodies to the extent that some of the

\footnotetext{
${ }^{25}$ Abū Hāmid al-Ghazālī, Ihyyà' 'Ulūm al-Dìn (Beirut: Dār al-Ma'rifah, 2005), 367 and 368.

${ }^{26}$ James, The V arieties of Religious Experience, 214.

27 Ibid., 234.

28 al-Qushayri, al-Qushayri's Epistle on Sufism, 109, 110, and 118.

${ }^{29}$ Schimmel, Mystical Dimension of Islam, 4.

30 El-Sayed El-Aswad, "Spiritual Genealogy: Sufism and Saintly Places in the Nile Delta", International Journal of Middle East Studies 38, no. 4 (2006), 507.
} 
performers would pass out in the middle of such sessions out of exhaustion. $^{31}$

\section{Final Goals of Mystical Practices}

\section{Cultivation of Sincerity}

Purification of intention is the ultimate goal of such practices. This is because the intention is an integral part of any action to the extent that no effort can be rewarded or even considered without having an intention. ${ }^{32}$ No one can deny the significance of sincerity or intention in every action, but what matters is what precedes the other, i.e., the intention precedes the bodily acts, or the action precedes the intention. While the first claim is mostly supported in multiple Islamic spheres, classical Sufi thought offers a conception of how bodily training acts are an active means used for nourishing intention and cultivating the feelings and certain ethics. In this meaning, al-Ghazāli maintains that obedience is the food of hearts as there is a close relationship between bodily acts and the hearts in which each affects the other..$^{33}$ The Sufi experience explains how outward bodily acts are responsible for constituting one's personality and how his interiority is formed. Asceticism involves this sort of discipline (such as fasting and mortification) of the self and body to an extreme degree to attain the maximum benefit of controlling feelings and sentiments and bringing them exclusively in line with God's commandments.

In the same vein, James details some sub-branches of discipline and self-mortification, as he says, "minor branches of selfmortification have been recognized as indispensable pathways to perfection..., obedience, and poverty [...] as vows to be observed." 34 For James, obedience represents a mystery to be perceived, but Sufi obedience is an intention to be cultivated. ${ }^{35}$ The complexity of its explanation or conceptualization may be one of the most challenging acts for how one can go against his wishes and fully obey outward commands voluntarily. But it can be easily conceived when one considers that the Suff's maxim is an embodiment of the prophetic hadith on the most challenging kind of jihäd (struggle) is Jihad against

31 Lindsay Rosenfeld, The Body in Remembrance Dhiker in Moroccan Sufism (California: University of North California: 2013), 44-45.

32 al-Ghazāin, Ibyä' 'Ulüm al-Din, 362.

33 Ibid., 367.

34 Ibid., 242.

35 Ibid., 367. 
the self. ${ }^{36}$ It is called jibäd al-nafs. To a Sufi, obedience is a complete sense of freedom; as Rumi states, "Forget your figuring. Forget your self. Listen to your friend. When you become totally obedient to that one, you will be free." ${ }^{37}$ The goal of this effort to cultivate willing obedience is ultimately to develop obedience to Allah's will. Furthermore, obedience to a master is a means for cultivating the humility required to forget the self, enabling one to attain that obedience to Allah's will. It is considered a victory against the self to develop contentment (rid $\vec{a}$ ) in this willing obedience. In turn, this contentment gives rise to trust (tawakkul) and freedom, as suggested by Rūmì.

In addition to obedience practices, in which one develops the intention to follow God's will through obedience to a master/teacher, poverty is another central element in Sufis's training. ${ }^{38}$ Poverty is one of the most paradoxical ascetic traits to be conceived, but it is a harmonious and reasonable quality in the classical Sufi context. ${ }^{39} \mathrm{Al}-$ Qushayri maintains that "Poverty is the hallmark of the friends of God (awliy $\bar{a})$, a decoration of the pure (asfiy $\bar{a})$, and the unique feature with which God-praise be to Him-distinguishes His elect ones from among the righteous and the prophets." ${ }^{\prime 40}$ Poverty was not just a carrier in the Sufi saintly journey, but it was the joyful and pleasurable medium that they eagerly struggle to use for divine satisfaction. Carl Ernst said, "The sign of the sincere Sufi is that he feels poor when he has wealth, is humble when he has power and is hidden when he has fame." ${ }^{41}$ Therefore, the practices discussed above are aimed at the creation of internal states and qualities that endure despite changing external circumstances.

Rūmī finds that the word Sufi means the one who wears only a woolen garment, meaning the poor; therefore, he suggests that the way to attain saintly goals is through poverty. ${ }^{42}$ Despite this poverty,

\footnotetext{
36 al-Qushayri, al-Qushayri's Epistle on Sufism, 118

${ }^{37}$ Llewellyn Vaughan-Lee, The Paradoxes of Love (California: The Golden Sufi Centre, 1996), 117.

38 al-Qushayri, Al-Qushayri's Epistle on Sufism, 280.

${ }^{39}$ Ibid.

40 al-Qushayri, al-Qushayri's Epistle on Sufism, 280.

${ }^{41}$ Carl W. Ernst, The Shambhala Guide to Sufism (Boston, Mass.: Shambhala, 1997), 30.

42 William C. Chittick, The Sufi Path of Love: The Spiritual Teachings of Rumi (USA: State University of New York Press, 1983), 187.
} 
the spiritual life of the Sufi also consists of acts of generosity. The spiritual generous saintly life can simply be conceived if one considers the sense of generosity in the words of James, "Fling yourself upon God's providence without making any reserve whatever, take no thought for the morrow, sell all you have and give it to the poor." ${ }^{43}$ This is called altruism (itharr) in Islamic terminology and refers to the preference of the other over one's self. İthär in Sufism signifies giving your brother whatever thing he/she wishes even if you require such thing as al-Junayd (d. 935), a Persian mystic and one of the most famous of the early Saints of Islam, notes. ${ }^{44}$

The Sufi saints see the outer appearance as less significant than the inner purity. In this meaning, al-Qushayrī states, "Renunciation of this world means cutting short one's hopes rather than eating coarse food or wearing a woolen cloak." ${ }^{45}$ What al-Qushayrī is suggesting here is that asceticism involves not only overt acts of poverty (e.g., wearing a woolen cloak), but also the adjustment of one's hopes and desires, i.e., internal states. James provides a psychological explanation of this ascetic goal, writing, "The craving for moral consistency and purity is developed to this degree, the subject may well find the outer world too full of shocks to dwell in, and can unify his life and keep his soul unspotted only by withdrawing from it." ${ }^{\prime 46}$ In other words, the withdrawal from worldly life is a means to achieving a moral purity that can be tarnished by extensive participation in 'the outer world.' While this ascetic withdrawal has been an essential part of the Sufi practice, many saints have also played critical social and political roles. $^{47}$

Wilaya, or saintliness, is the technical term for the spiritual case in which the person enters to be like an angel in purity. Thus, the saint (wali pl. awliya $\bar{a}$ ) is one who possesses a quality of spiritual closeness to Allah. In other words, awliy $\bar{a}$ ' are special people chosen by God and endowed with exceptional gifts, such as the ability to work miracles. ${ }^{48}$ Al-Qushayrī defines the term Wali by two meanings;

${ }^{43}$ James, The V arieties of Religious Experience, 250.

${ }_{44}$ Abū al-Qāsim al-Junayd, Tāj al-'Árifin al-Junayd al-Baghdādì, edit. Su'ād al-Hakīm (Beirut: Dār al-Shurūq, 2004), 182.

${ }^{45}$ al-Qushayri, al-Qushayri's Epistle on Sufism, 135.

46 Ibid., 231.

${ }^{47}$ Green, Sufism.

48 Radtke Bernd, "Saints", in Jane Dammen McAuliffe (ed.), Encyclopaedia of the Qur'ān (Leiden: Brill, 2001), 520; Ade Kurniawan, Noorhaidi Hasan, and Achmad 
the first is God's care for his friends, and the second is the strict adherence of the Wali to God's way and avoidance of His disobedience. ${ }^{49}$ Carl Ernst holds that Wali is a figure who could intercede with God, much as a feudal noble could intercede with the king. ${ }^{50} \mathrm{It}$ is worthy of mention that the term Wilaya was developed in the second half of the ninth century by al-Hāakim al-Tirmīdhī (d. 912), (a Sunnī jurist (faqih) and traditionist (mubaddith) of Khorasan, and one of the great early authors of Sufism). Later authors, such as Ibn Arabi, had to expand on al-Tirmīdhì's ideas. ${ }^{51}$

While these definitions of wali focus on the attributes possessed by an individual, Vincent Cornell notes, "Walaya and wilàya are used interchangeably by most Western scholars of Islam ... the terms wati Allah has a social as well as a metaphysical signification: the Muslim saint protects or intercedes for others as Allah's deputy or viceregent. ${ }^{, 52}$ In other words, sainthood has both a spiritual and social significance. With regard to the spiritual, it refers to the possession of certain characteristics and abilities that are acquired through closeness to the divine. With regard to the social, it relates to the ability to perform specific social actions as a result of that state of closeness.

A $W$ ali is the one whose soul is so pure and has a transparent heart through which he/she can see by God's eyes and hear by God's ears and walk by God's support. His life is like a bird's life in terms of perfect trust in God, and quietism fills his heart. He fully trusts that God drives rizg (provision) for him/her without any human being's interference. This $W$ ali has an inner power and lives in a broader life than the ordinary person. As William James maintains, the saint lives on a more expansive world than this selfish life of futile concerns and is empowered by a belief that there is an Ideal Power that protects

\footnotetext{
Zainal Arifin, "Wali and Karama: A Discourse and Authority Contestation in alTarmasi's Bughyat al-Adbkiya", al-Jami'ab: Journal of Islamic Studies 57, no. 2 (2019), 291. DOI: https://doi.org/10.14421/ajis.2019.572.287-328.

49 'Abd al-Fattāh 'Abd Allah Barakah, al-Hakim al-Tirmidhi wa Naz̧arìyatuh fì al-Wilāya (Cairo: Majma’ al-Buhūth al-Islāmiyya, 2001), 65.

${ }^{50}$ Ernst, The Shambhala Guide, 50.

${ }^{51}$ Bernd, "Saints", 520. Aiyub Palmer, Sainthood and Authority in Early Islam: al-Hakim al-Tirmidhi's Theory of Wilaya and the Reenvisioning of the Sunni Caliphate (Leiden; Boston: Brill, 2020).

52 Vincent Cornell, Realm of the Saint: Power and Authority in Moroccan Sufism (Texas: University of Texas Press, 1998), 65.
} 
him/her. ${ }^{53}$ Such power springs from his/her sincere belief and exclusive dependence on God.

One way in which the concept of sainthood has been approached by scholars through the notion of baraka (blessing), that is, as a kind of spiritual power held by the saint. ${ }^{54}$ Others have approached it as a social construction, arguing that the saint is only established insofar as he is recognized as such through the performance of particular acts. ${ }^{55}$ Finally, others suggest that the saint is one who possesses a specific ethical character (sälih)..$^{56}$ While there are various conceptions of sainthood, I approach sainthood for the present purposes in the following way.

\section{God's Care}

God's care is the source of power inspired into the hearts of saints. They acquire a unique feeling that distinguishes them from ordinary people. They do not share the same life concerns or interests as others and show indifference to worldly matters. This what James refers to as "a sense of the friendly continuity of the ideal power with people's own life, and a willing self-surrender to its control." ${ }^{\circ 7}$ This sense is not separable from the sense of "the presence of a higher and friendly Power," 58 which is a common feeling of all Sufi saints of different tariqa (way/order) through which they feel that as if they are not alone in their solitude but always accompanied by God's spirit. Sufism's sense of God's presence is common and observed by most authors who wrote about this mystic experience as, Martin van Bruinessen and Julia Day Howell, in their "Sufism and the 'modern' in Islam," argue that Sufis tend to "a radical shift in awareness through which God's presence is felt more intensely." 59 The Sufi doctrine of "the presence of God" inside their hearts is because of their conviction that the heart is the permanent abode of God or, in other words, the mirror that reflects God. ${ }^{60}$ The presence of higher

\footnotetext{
53 Ibid., 212.

${ }^{54}$ Ibid.

${ }^{55}$ Green, Sufism, 71.

${ }^{56}$ Schimmel, Mystical Dimension of Islam, 199.

57 Ibid., 213.

58 Ibid., 214.

${ }^{59}$ Martin van Bruinessen and Julia Day Howell, Sufism and the 'Modern' in Islam (New York: I.B. Tauris \& Co. Ltd, 2007), 7.

${ }^{60}$ Schimmel, Mystical Dimension of Islam, 190.
} 
power always accompanies the Sufi saint, but the striking question is that what pushes the Sufi heart to be filled with such Divine Presence? It is the Divine love which is "like the falcon which carries away the prey," separating him, thus, from all that is created in time," as Schimmel argues. ${ }^{61}$ The saintly spiritual life is not just an escape from reality; however, the saint lives in both worlds voluntarily and chooses to dedicate his life to such a saintly experience. Thus, one fruit of the saintly life is an enduring sense of presence that permeates one's life, constantly guiding one's actions and intentions. As such, it leads individuals to consider their actions not in light of their own egoistic and material desires but in light of goods that go beyond themselves.

In contrast to servitude to worldly gains, which amplify one's egoism and attachment to material goods, the next fruit of saintly life is freedom, which may be seen as a paradoxical trait in this context. It is paradoxical in the sense that freedom is acquired through the negation of one's own will and the affirmation of God's will. Therefore, freedom is achieved through service to God's will. In other words, Sufi saints strive to free themselves from the servitude of people or attachment to worldly gains to be guided only by divine demands. Al-Qushayrī holds that freedom signifies that the slave of God does not allow himself to be enslaved by creatures, nor be enslaved by the power of originated things (mukawwanat $)^{62}$ According to Ruwaym, a Muslim jurist and saint, Sufism is equivalent to freedom as it is a case of being delivered from worldly and self-constrains and generous to others in the attempt to overcome bodily needs and desires. ${ }^{63}$ The first requirement for achieving one's liberty from attachment to earthly needs is self-awareness that balances one's interior and the external world. ${ }^{64}$ Such awareness involves a power to detect and redress the self's defects and within a perfectly spiritual experience. The entailing sense of freedom is thus a springboard in Sufi life. Once the Sufi individual frees himself/herself from worldly restrictions and starts the journey towards the one "Reality," will receive an internal "light" 66 that guides him through, and then this

\footnotetext{
${ }^{61}$ Ibid., 4.

${ }^{62}$ al-Qushayri, Al-Qushayri's Epistle on Sufism, 229.

${ }^{63}$ Schimmel, Mystical Dimension of Islam, 15.

${ }^{64}$ El-Aswad, "Spiritual Genealogy", 508.

${ }^{65}$ Schimmel, Mystical Dimension of Islam, 4.

${ }^{66}$ Ibid.
} 
"light becomes stronger as one frees himself/herself from the attachments to this world or-as the Sufis would say-polishes the mirror of his heart." ${ }^{67}$ Then, a person undergoes a long period of training to achieve utmost purification towards receiving-what Annemarie Schimmel describes as-the "love and gnosis [...] he may reach the last goal of all mystical quest, the unio mystica (union of the soul with God)", ${ }^{68}$

\section{Purity}

Purity is another fruit of abandoning earthly (lustful) desires. Once the Sufi saint diverts his/her longing for worldly needs and goes towards the divine demands, spiritual cleanliness and purification settle in his/her heart. William James notes that the "shifting of the emotional center brings with it, first, increase of purity $[. .$.$] the saintly$ life must deepen its spiritual consistency and keep unspotted from the world." ${ }^{69}$ According to one of the various definitions for the term Sufism, there is a suggestion that the word Sufi is derived from purity, just as Schimmel maintains that the root of the word Sufi is safä, "purity". ${ }^{70}$ Sufism's supreme goal by following the mystic path in life makes the heart ready to receive the divine light because pure hearts are the most qualified to receive this divine light. This is precisely one of the Sufi teachings' ultimate goals, which aim at inuring humans to attain such enlightenment in their ordinary life. ${ }^{71}$

\section{Divine Intuition}

Still, relinquishment of material desires could by itself be insufficient in nurturing intuitive discretion, insight, kashf (intuitive knowledge), or basiira (foresight). ${ }^{72}$ According to Fethullah Gulen,such foresight means "having an eye of the heart open, deep perception, an ability to see consequences at the beginning of an act,

\footnotetext{
${ }^{67}$ Ibid.

${ }^{68}$ Ibid., 4.

${ }^{69}$ James, The Varieties of Religious Experience, 214.

${ }^{70}$ Schimmel, Mystical Dimension of Islam, 16.

${ }^{71}$ Nasir and Malik, Role and Importance of Sufism, 2.

72 Joseph E. B. Lumbard, "From "Hubb" to "'Ishq": The Development of Love in Early Sufism", Journal of Islamic Studies 18, no. 3 (2007), 345-385. http:// www.jstor.org/stable/26200249.
} 
or foresight," just as it is "a power of conscience," by seeking the path of mysticism. ${ }^{74}$ Because of knowledge is a light from God, the way to attain it is by disciplining the bowl or container (the self) which will receive it. "The Qur'ān puts unusual emphasis upon ilm, "knowledge," both discursive and spiritual, in order for the human being to "know" his own "self. Such knowledge of the "self" leads to the knowledge of God". ${ }^{75}$ This exceptional faculty is almost ascribed to few Sufi notables who are claimed to have assimilated divine secret and light within their hearts. This light is deemed to grant them an ability to access some hidden facts beyond ordinary people's reach. It is the so-called 'Ilm Ladunni (hidden divine knowledge) or "interior knowledge that is acquired via God's illumination." 76 This kind of knowledge is not transmitted to Sufi disciples through books but rather through permanent attentive discipleship to the saint. ${ }^{77}$ Some authors argue that the term shabajda (There is no God but Allah; the first pillar of Islam) in Islam implies a mystery. Only a Sufi saint can decipher or interpret it in its mysterious sense saints are the chosen ones who can genuinely perceive God. ${ }^{78}$ It is not surprising that this transcendental faculty goes in line with the saints' internal knowledge's singularity. In Sufi terminology, this is embodied in the figure of the "Qutb" (literally, pole); or a Sufi saint who attains the honor of having intimacy with God. Those of the highest quality who can obtain this hidden knowledge and guide people are often referred to as the "Qutb" or pole of sainthood. As a carrier of the divine illumination brought down through prophets, a Qutb has an exceptional role in reviving faith. ${ }^{79}$ Qutbiyya (being Qutb)

\footnotetext{
${ }^{73}$ M. Fethullah Gulen, "Basira and Firasa", Fountain Magazine, Issue 91, 1 January 2013.

${ }^{74}$ Schimmel, Mystical Dimension of Islam, 193.

${ }^{75}$ Syed M. Waqas, “The Qur'ānic Dialogue with the Mystical Theology of Logos in John's Gospel”. Teosofi: Jurnal Tasawuf dan Pemikiran Islam 10, no. 2 (December 20, 2020): 179-203. http://jurnalfuf.uinsby.ac.id/index.php/teosofi/article/view/1517.

${ }^{76}$ El-Aswad, "Spiritual Genealogy", 508. Duncan Black MacDonald, "The Life of al-Ghazzālī, with Especial Reference to His Religious Experiences and Opinions", Journal of the American Oriental Society 20 (1899), 71-132. https://www.jstor.org /stable/592319.

${ }_{77}$ Ibid.

78 Shahida Bilqies, "Understanding the Concept of Islamic Sufism", Journal of Education \& Social Policy 1, no. 1 (2014), 2.

${ }^{79}$ Jamal Malik and John Hinnells, Sufism in the West (New York: Routledge, 2006), 98.
} 
is the ultimate rank in saintly life and is accessible only by a few Sufi saints when they reach the peak of pure knowledge. It embodies the maximum capacity of the human heart when aided by God's Grace or illumination. ${ }^{80}$ This is a unique characteristic of Sufi saintliness that resonates with the Jamesian notion of "Noetic Quality," through which mystical states also seem to be states of knowledge. These are states of insight into the depths of truth unplumbed by the discursive intellect. ${ }^{81}$ They are revelations, effusions, full of significance as expressed in Sufi Fuyùdàt (illuminations or influx of divine light).

\section{Freedom and Spiritual Brotherhood}

In addition to the fruits of constant remembrance and freedom, another fruit that has implications for social life assures the significance of saintliness at a community level, i.e., 'brotherly or fraternal love.' In a saintly life, this fruit is cultivated as a state of mind. ${ }^{82}$ So, while materialism intensifies individualistic dispositions, saintly preach brings something different. The Sufi teachings thus give precedence to the Islamic idea of faith-based fraternity over biological brotherhood. The spiritual experience liberates people from blood and tribal affiliations and provides them with spiritual and social alternates. ${ }^{83}$ The saintly concept of brotherhood is different from any other sense of religious or nationalist brotherhood. It is a sense that surpasses the limits of religion, race, color, or blood. Ideally represented in James's words, "the saint loves his enemies, and treats loathsome beggars as his brothers." 84 The ability to see beyond these forms of difference is a crucial component of the saintly life. This ability, however, is dependent upon the creation of certain social qualities, such as altruism (ithär), humility (tawāạ) and generosity (karam/sakhä), that are characteristics of the Sufi saint. The saint is also characterized by certain spiritual qualities that give deep insight into reality and constantly anchor one's thought and action in divine presence and love. Therefore, the social significance of the saintly life embodied in Sufism is that it can create individuals with social

\footnotetext{
${ }^{80}$ Ibid., 94.

${ }^{81}$ James, The Varieties of Religious Experience, 295.

82 Ibid., 218.

${ }^{83}$ El-Aswad, "Spiritual Genealogy", 508.

${ }^{84}$ James, The V arieties of Religious Experience, 214.
} 
qualities that can facilitate feelings of fellowship while also providing spiritual alternatives to the aims of materialistic life.

\section{Concluding Remarks}

Through these sublime manifestations of the spiritual, Islamic saintliness has played a vital role in nourishing the Muslims' spiritual life over the ages, under various senses and terms. This mystic movement in Islam falls in line with the Islamic focus on the spiritual element in life. Besides, some common aspects of saintliness are shared by all religions and represented in mystic practices aimed at qualifying the individual for saintly life. Yet, each religion has its unique mystic practices and statuses, as expressed in the Sufi notions of Qutb and Kashf. The mystic practices may seem unreasonable for ordinary people, though they go in line with the world's unique saintly perception. Abiding by these mystic practices paves the way for attaining a range of spiritual fruits that the saints consider heavenly.

On the whole, saints are claimed to gain supernatural powers that may also seem illogical to the ordinary person. However, the Sufis believe these gains can only be attained through the excessive refinement of the soul, which could at times be considered supernatural per se. It is in this sense that James' following statement seems natural, "The great saints are immediate successes; $[. .$.$] let us$ be saints, then, if we can, whether or not we succeed." ${ }^{85}$

\section{Bibliography}

Ābidīn, Muhammad Amīn b. Radd al-Mubtār 'alā al-Durr al-Mukbtār: Sharh Tanwìr al-Absār, ed. ed. Ādil Aḥmad 'Abd al-Mawjūd et al., Vol. 6. Riyadh: Dār 'Ālam al-Kutub, 2003.

al-Qushayri, Abu al-Qasim. al-Qushayri's Epistle on Sufism, trans. Alexander Knysh. UK: Garnet Publishing Limited, 2007.

Baldock, John. The Essence of Sufism. n.p.: Arcutrus Publishing, 2005.

Barakah, 'Abd al-Fattāh 'Abd Allah. al-Hakim al-Tirmidhì wa Naz̧arȳyatub fì al-Wilāya. Cairo: Majma’ al-Buhūth al-Islāmiyya, 2001.

Bernd, Radtke. "Saints", in Jane Dammen McAuliffe (ed.), Encyclopaedia of the Qur' ann. Leiden: Brill, 2001.

Bilqies, Shahida. "Understanding the Concept of Islamic Sufism", Journal of Education \& Social Policy 1, no. 1, 2014.

85 Ibid., 292. 
Bruinessen, Martin van and Howell, Julia Day. Sufism and the 'Modern' in Islam. New York: I.B.Tauris \& Co. Ltd, 2007.

Chittick, William C. The Sufi Path of Love: The Spiritual Teachings of Rumi. USA: State University of New York Press, 1983.

Cornell, Vincent. Realm of the Saint: Power and Authority in Moroccan Sufism. Texas: University of Texas Press, 1998.

El-Aswad, El-Sayed. "Spiritual Genealogy: Sufism and Saintly Places in the Nile Delta", International Journal of Middle East Studies 38, no. 4, 2006.

Ernst, Carl W. The Shambhala Guide to Sufism. Boston, Mass.: Shambhala, 1997.

Ghazāầ (al), Abū Hạ̄mid. Ihyà̃' 'Ulūm al-Dìn. Beirut: Dār al-Ma'rifah, 2005.

Gulen, M. Fethullah. "Basira and Firasa", Fountain Magazine, Issue 91, 1 January 2013.

James, William. The Varieties of Religious Experience. London: Routledge, 2002.

Junayd (al), Abū al-Qāsim. Täj al-'Árifiñ al-Junayd al-Baghdādì, edit. Suād al-Hakīm. Beirut: Dār al-Shurūq, 2004), 182.

Jung, Carl Gustav. Modern Man in Search of Soul, trans. W.S Dell and Cary F. Bynes. London: Routledge, 2005.

Kurniawan, Ade., Hasan, Noorhaidi., and Arifin, Achmad Zainal. "Wali and Karama: A Discourse and Authority Contestation in al-Tarmasi's Bughyat al-Adbkiya", al-Jami'ab: Journal of Islamic Studies 57, no. 2, 2019. DOI: https://doi.org/10.14421/ ajis.2019.572.287-328.

Lumbard, Joseph E. B. "From "Hubb" to "Ishq": The Development of Love in Early Sufism", Journal of Islamic Studies 18, no. 3, 2007. http://www.jstor.org/stable/26200249.

Macdonald, Duncan Black. "The Life of al-Ghazzālī, with Especial Reference to His Religious Experiences and Opinions", Journal of the American Oriental Society 20, 1899. https://www.jstor.org/stable/592319.

-----. The Religious Attitude and Life in Islam. Chicago: University of Chicago Press, 1909.

Malik, Jamal and Hinnells, John. Sufism in the West. New York: Routledge, 2006. 
Nasir, Rabia and Malik, Arsheed Ahmad. "Role and Importance of Sufism in Modern World," International Journal of Advancements in Research \& Technology 2, no. 1, January 2013.

Nasr, Seyyed Hossein. The Garden of Truth: The Vision and Promise of Sufism, Islam's Mystical Tradition. New York: Harper Collins, 2008.

Palmer, Aiyub. Sainthood and Authority in Early Islam: al-Hakim alTirmidhi's Theory of Wilaya and the Reenvisioning of the Sunni Caliphate. Leiden; Boston: Brill, 2020.

Pullella, Philip. "Remember the Poor and Shun Materialism, Pope Says on Christmas Eve", Reuters, 24 December, 2018.

Rosenfeld, Lindsay. The Body in Remembrance Dhiker in Moroccan Sufism. California: University of North California: 2013.

Schimmel, Annemarie. Mystical Dimension of Islam. University of North Carolina Press: USA, 1975.

Vaughan-Lee, Llewellyn. The Paradoxes of Love. California: The Golden Sufi Centre, 1996.

Waqas, Syed M. “The Qur'ānic Dialogue with the Mystical Theology of Logos in John's Gospel”. Teosofi: Jurnal Tasawuf dan Pemikiran Islam 10, no. 2, 2020. http:// jurnalfuf.uinsby.ac.id/index.php/ teosofi/article/view/1517. 